\title{
The accumulation of elements in plants growing spontaneously on small heaps left by the historical $\mathrm{Zn}$-Pb ore mining
}

\author{
Anna M. Stefanowicz ${ }^{1} \cdot$ Malgorzata Stanek $^{1} \cdot$ Marcin W. Woch $^{2} \cdot$ Pawel Kapusta $^{1}$
}

Received: 23 July 2015 / Accepted: 23 November 2015 /Published online: 4 December 2015

(C) The Author(s) 2015. This article is published with open access at Springerlink.com

\begin{abstract}
The study evaluated the levels of nine metals, namely $\mathrm{Ca}, \mathrm{Cd}, \mathrm{Fe}, \mathrm{K}, \mathrm{Mg}, \mathrm{Mn}, \mathrm{Pb}, \mathrm{Tl}$, and $\mathrm{Zn}$, in soils and tissues of ten plant species growing spontaneously on heaps left by historical mining for $\mathrm{Zn}-\mathrm{Pb}$ ores. The concentrations of $\mathrm{Cd}, \mathrm{Pb}, \mathrm{Tl}$, and $\mathrm{Zn}$ in heap soils were much higher than in control soils. Plants growing on heaps accumulated excessive amounts of these ele-
\end{abstract}

Responsible editor: Elena Maestri

Highlights The contents of nine elements in ten plant species from old polluted heaps were studied.

$\mathrm{Cd}, \mathrm{Pb}, \mathrm{Tl}$, and $\mathrm{Zn}$ contents were 1.5-540 times higher in heap than in control plants.

Heap plants also tended to be enriched in $\mathrm{K}$ and $\mathrm{Mg}$, and impoverished in $\mathrm{Ca}, \mathrm{Fe}$, and $\mathrm{Mn}$.

The contents of $\mathrm{Cd}, \mathrm{Fe}, \mathrm{Pb}, \mathrm{Tl}$, and $\mathrm{Zn}$ were generally higher in roots than in shoots.

$\mathrm{Cd}, \mathrm{Pb}$, and $\mathrm{Zn}$ in plant tissues correlated positively with the metals in soil.

Electronic supplementary material The online version of this article (doi:10.1007/s11356-015-5859-7) contains supplementary material, which is available to authorized users.

Anna M. Stefanowicz

a.stefanowicz@botany.pl

Małgorzata Stanek

m.stanek@botany.pl

Marcin W. Woch

jurania@up.krakow.pl

Paweł Kapusta

p.kapusta@botany.pl

1 W. Szafer Institute of Botany, Polish Academy of Sciences, Lubicz 46, 31-512 Kraków, Poland

2 Institute of Biology, Pedagogical University of Kraków, Podchorażych 2, 31-054 Kraków, Poland ments in tissues, on average $1.3-52 \mathrm{mg} \mathrm{Cd} \mathrm{kg}{ }^{-1}, 9.4-254 \mathrm{mg}$ $\mathrm{Pb} \mathrm{kg}{ }^{-1}, 0.06-23 \mathrm{mg} \mathrm{Tl} \mathrm{kg}{ }^{-1}$ and $134-1479 \mathrm{mg} \mathrm{Zn} \mathrm{kg}^{-1}$ in comparison to $0.5-1.1 \mathrm{mg} \mathrm{Cd} \mathrm{kg}^{-1}, 2.1-11 \mathrm{mg} \mathrm{Pb} \mathrm{kg}^{-1}, 0.02$ $0.06 \mathrm{mg} \mathrm{Tl} \mathrm{kg}^{-1}$, and $23-124 \mathrm{mg} \mathrm{Zn} \mathrm{kg}^{-1}$ in control plants. The highest concentrations of $\mathrm{Cd}, \mathrm{Pb}$, and $\mathrm{Zn}$ were found in the roots of Euphorbia cyparissias, Fragaria vesca, and Potentilla arenaria, and $\mathrm{Tl}$ in Plantago lanceolata. Many species growing on heaps were enriched in $\mathrm{K}$ and $\mathrm{Mg}$, and depleted in $\mathrm{Ca}, \mathrm{Fe}$, and $\mathrm{Mn}$. The concentrations of all elements in plant tissues were dependent on species, organ (root vs. shoot), and species-organ interactions. Average concentrations of $\mathrm{Ca}, \mathrm{K}$, and $\mathrm{Mg}$ were generally higher in shoots than in roots or similar in the two organs, whereas $\mathrm{Cd}, \mathrm{Fe}, \mathrm{Pb}, \mathrm{Tl}$, and $\mathrm{Zn}$ were accumulated predominantly in the roots. Our results imply that heaps left by historical mining for $\mathrm{Zn}-\mathrm{Pb}$ ores may pose a potential threat to the environment and human health.

Keywords Historical mining · Heavy metal accumulation . Plant tissues $\cdot$ Bioconcentration factor $\cdot$ Translocation factor

\section{Introduction}

Contaminated sites left by historical mining and processing of metal ores, abandoned tens or hundreds of years ago, may be difficult to evaluate in terms of environmental risk, as they are often not recorded in written documents and not known to the local authorities (Eckel et al. 2001). Relics of the former metal industry, such as waste heaps, tend to disappear from the landscape, for example as a result of the denudation process. Even if the waste heaps can be visually detected in the field, their inventory is still a difficult task because the heaps are often small and scattered over a wide area (Aleksander-Kwaterczak 
and Ciszewski 2013; Stefanowicz et al. 2014). Unfortunately, the disappearance of traces of the ancient metal industry from the landscape is not followed by the loss of heavy metals from the environment. It is known that these metals may persist in high concentrations for decades, centuries, or even millennia not only at the contamination sources but also in adjacent agricultural soils, sediments, and surface waters, to which they are gradually transported (Adams et al. 2007; Grattan et al. 2003; Harrison et al. 2003; Pyatt et al. 2005; Stefanowicz et al. 2014; Tatsi and Turner 2014; Teršič et al. 2009).

Western Małopolska, located in southern Poland, is one of the oldest regions of mining and processing of metal ores in Central Europe. These activities have lasted there for centuries, leaving traces, such as old heaps of waste rock (Aleksander-Kwaterczak and Ciszewski 2013; Stefanowicz et al. 2014). The heaps are small, inconspicuous, and frequently masked by vegetation. They occur in high numbers over an extended area, singly or in groups, in the latter case forming a characteristic undulating surface. Recently, we analyzed soils developed on several dozen of non-forested heaps and found that they contain large amounts of heavy metals, in extreme cases: $520 \mathrm{mg} \mathrm{Cd} \mathrm{kg}^{-1}, 23,000 \mathrm{mg} \mathrm{Pb} \mathrm{kg}^{-1}, 50 \mathrm{mg} \mathrm{Tl} \mathrm{kg}^{-1}$, and $70,400 \mathrm{mg} \mathrm{Zn} \mathrm{kg}^{-1}$. These heaps are, therefore, "hot-spots" of metal contamination, which can affect neighboring agricultural land or vegetable gardens and pose a potential threat to human health (Stefanowicz et al. 2014).

Old heaps found in non-forested areas are covered with relatively dense vegetation (Woch et al. 2015). This vegetation consists predominantly of herbaceous species that commonly grow on unpolluted soils, but show a relatively high tolerance to heavy metals and are also able to colonize metalliferous soils (Woch et al. 2015). Although most herbaceous species growing on old heaps are small and do not produce great amount of biomass, they occur frequently, possibly exerting a meaningful influence on the metal fate in the ecosystem. Most of the plants that survive on metalliferous soils accumulate heavy metals in the roots and restrict their transport to the aerial parts, being potentially useful in phytostabilization, which focuses on immobilization of pollutants (Dahmani-Muller et al. 2000; Yoon et al. 2006). The opposite strategy is based on active transport of elements from roots to shoots, which leads to their accumulation in aboveground plant tissues (Pollard et al. 2014). In the case of heavy metals, such accumulation poses a risk of metal transfer to higher strata of the food chain (Peralta-Videa et al. 2009). Even if a given metal is not readily available in the soil, its uptake by an accumulator plant can make it available to soil organisms, insects, and grazers (Mertens et al. 2005). This problem was reported by Pyatt et al. (2000). who found that both plants and herbivores, including goats, living in a polluted area of ancient metal mining in Jordan, contained elevated heavy metal concentrations in their tissues.
The aim of this research was to analyze the concentrations of nine metals, namely $\mathrm{Ca}, \mathrm{Cd}, \mathrm{Fe}, \mathrm{K}, \mathrm{Mg}, \mathrm{Mn}, \mathrm{Pb}$, $\mathrm{Tl}$, and $\mathrm{Zn}$, in shoots and roots of ten species of herbaceous plants growing spontaneously on the heaps of waste rock left by historical $\mathrm{Zn}-\mathrm{Pb}$ ore mining. These concentrations were compared with the corresponding concentrations of metals in the plant from control sites and referred to metal contents in the soil. Plant/soil and shoot/root ratios were calculated to determine the strategy of particular plant species regarding metal management, the potential risk of heavy metal diffusion in the food web, and the usefulness of selected plant species in phytoremediation of heavy metal-contaminated lands.

\section{Materials and methods}

\section{Study area and sampling}

The location of the study area and waste heaps is presented in Fig. 1. The area was described in terms of geology and the history of $\mathrm{Zn}-\mathrm{Pb}$ ore mining in Stefanowicz et al. (2014). The heaps were on average $0.5-2 \mathrm{~m}$ high and from several to tens $\mathrm{m}$ in diameter. They were covered by calcareous grasslands of Carlino acaulis-Brometum erecti association, the dominant variant of which was loose heavy metal grassland with Festuca ovina as the main component (Woch et al. 2015).

Soil and plant (shoots and roots) samples were collected in summer 2012. Ten herbaceous species were selected for the study: Achillea collina Becker ex Rchb. (Asteraceae), Carex hirta L. (Cyperaceae), Euphorbia cyparissias L. (Euphorbiaceae), Fragaria vesca L. (Rosaceae), Hieracium pilosella L. (Asteraceae), Leontodon hispidus L. (Asteraceae), Plantago lanceolata L. (Plantaginaceae), Potentilla arenaria Borkh. (Rosaceae), Rumex acetosa L. (Polygonaceae), and Scabiosa ochroleuca L. (Dipsacaceae). These species were chosen because they commonly occur on both contaminated and uncontaminated soils, and, with the exception of $P$. lanceolata, have been rarely studied in respect of metal accumulation (Dimitrova and Yurukova 2005; Nadgórska-Socha et al. 2013; Orłowska et al. 2002; Szarek-Łukaszewska and Niklińska 2002; Wójcik et al. 2014). All plant species were collected from seven heaps (one set of species per heap; Fig. 1). This sampling scheme allowed to compare tissue metal levels between species that grow under the same soil conditions, avoiding pseudoreplication. Samples of five species, i.e., $C$. hirta, $F$. vesca, $H$. pilosella, $P$. arenaria, $P$. lanceolata, were collected from 11 additional heaps to be able to study the relationships between soil and plant metal concentrations $(N=18$; Fig. 1$)$. Three topsoil $(0-15 \mathrm{~cm})$ subsamples were collected at each site following careful removal of the organic $(\mathrm{O})$ horizon; the three subsamples were bulked into one composite sample. Five control sites were established 

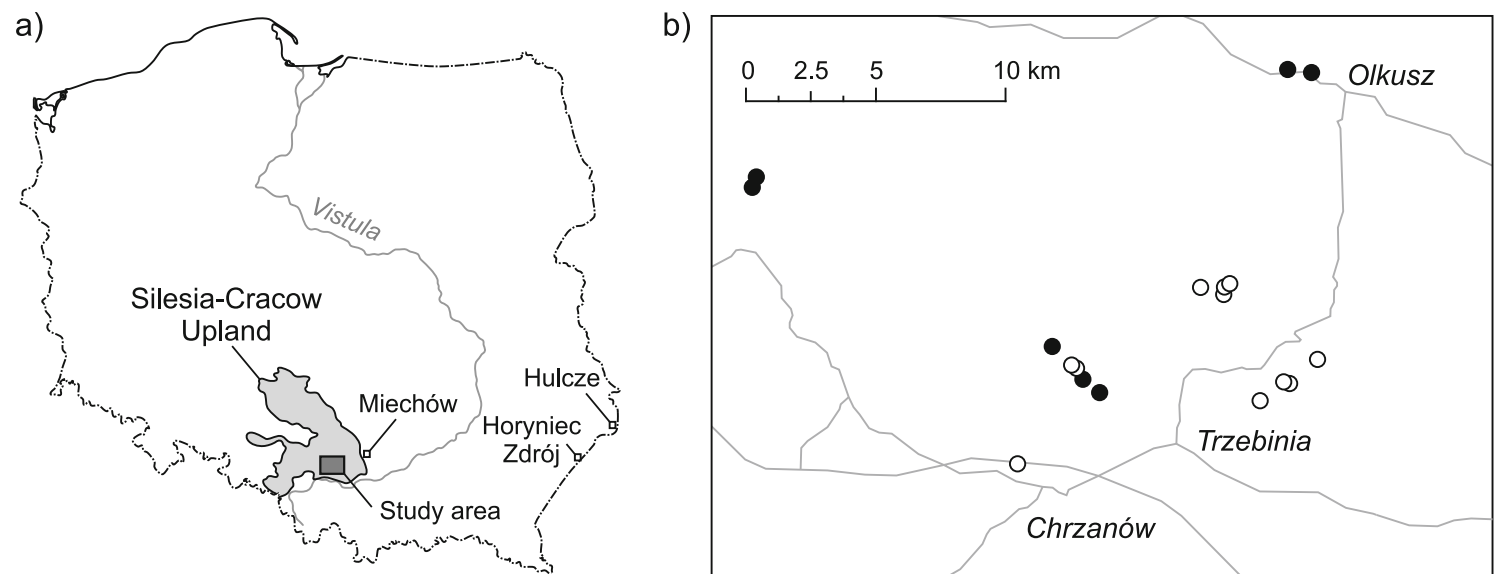

Fig. 1 Location of (a) the study area and control sites and (b) heaps, from which ten (black circles) or five (white circles) plant species were collected. Major cities and main roads are also indicated

near Horyniec Zdrój and Hulcze in south-eastern Poland and near Miechów in southern Poland, similar in geology to the main study area, but remote from anthropogenic sources of pollution (Fig. 1; Stefanowicz et al. 2014). Soil samples were collected from each control location as described above $(N=5)$. We were not able to find the whole set of plant species at all control sites, thus the control plants were collected from one to three sites (depending on the species). A single species sample from each heap and each control site consisted of three subsamples (specimens).

\section{Laboratory work}

Soil samples were sieved (2-mm mesh) and dried at $105^{\circ} \mathrm{C}$. Soil texture was determined through a combination of sieving and sedimentation, and soil $\mathrm{pH}$ was tested with a $\mathrm{pH}$-meter (Hach HQ40d) after extraction with water at a 1:5 (w:v) ratio. Organic carbon was assessed using a dry combustion technique with a Leco RC-612. Total nitrogen was measured using the Kjeldahl method; soil was digested in $\mathrm{H}_{2} \mathrm{SO}_{4}$ with Kjeltabs $\left(\mathrm{K}_{2} \mathrm{SO}_{4}+\mathrm{CuSO}_{4} \cdot 5 \mathrm{H}_{2} \mathrm{O}\right.$; Foss Tecator Digestor Auto) followed by distillation on the Foss Tecator Kjeltec 2300 Analyzer Unit. To determine the concentration of the different forms of metals in soil, four soil extraction methods were applied. Total $\mathrm{Ca}, \mathrm{Cd}, \mathrm{Fe}, \mathrm{K}, \mathrm{Mg}, \mathrm{Mn}, \mathrm{Pb}, \mathrm{Tl}$, and $\mathrm{Zn}$ were extracted by digestion of soil with hot concentrated $\mathrm{HClO}_{4}$ (Foss Tecator Digestor Auto). Mobile metals were extracted by shaking the soil samples for $1 \mathrm{~h}$ with $0.05 \mathrm{M}$ EDTA $(\mathrm{Cd}$, $\mathrm{Pb}, \mathrm{Tl}, \mathrm{Zn}), 0.1 \mathrm{M} \mathrm{BaCl}_{2}$ at $\mathrm{pH} 7.0(\mathrm{Ca}, \mathrm{Cd}, \mathrm{Fe}, \mathrm{K}, \mathrm{Mg}, \mathrm{Mn}$, $\mathrm{Pb}, \mathrm{Tl}, \mathrm{Zn})$, and deionized water $(\mathrm{Cd}, \mathrm{Pb}, \mathrm{Tl}, \mathrm{Zn})$. Metal contents in soil extracts were analyzed with flame or graphite furnace (water-extractable metals) atomic absorption spectrometry (Varian AA220FS, GTA 110). Certified reference materials were used to estimate the quality of the metal analyses: CRM048-050 (RTC; total), BCR-483 (IRMM; EDTAextractable), and ISE-912 (WEPAL; $\mathrm{BaCl}_{2}$-extractable); for EDTA and $\mathrm{BaCl}_{2}$, certified or indicative values were given only for selected metals. The recovery values ranged from 94 to $102 \%$ for total metal contents, from 91 to $98 \%$ for EDTA-extractable metals and from 93 to $97 \%$ for $\mathrm{BaCl}_{2}$ extractable metals.

The collected plants were deprived of brown dead leaves and washed carefully in running tap water, followed by double distilled and deionized water. The plants were divided into shoots and roots and dried at $80{ }^{\circ} \mathrm{C}$ for $48 \mathrm{~h}$. To analyze the elemental composition, the plant material was ground and digested in a hot concentrated mixture of $\mathrm{HNO}_{3}$ and $\mathrm{HClO}_{4}$ (4:1; Foss Tecator Digestor Auto). The concentrations of Ca, $\mathrm{Cd}, \mathrm{Fe}, \mathrm{K}, \mathrm{Mg}, \mathrm{Mn}, \mathrm{Pb}, \mathrm{Tl}$, and $\mathrm{Zn}$ were analyzed using flame or graphite furnace atomic absorption spectrometry (Varian AA280FS; Varian AA280Z, GTA 120). Certified reference materials, Oriental Basma Tobacco Leaves INCT-OBTL-5 (The Institute of Nuclear Chemistry and Technology) and moss Pleurozium schreberi M2 (The Finnish Forest Research Institute) were used to test the quality of metal analyses in plants. The recovery values for plant extracts ranged from 92 to $113 \%$.

\section{Calculations and statistical analyses}

For all metals and plant species, bioconcentration (BCF) and translocation factors (TF) were calculated. BCF is the ratio of plant/soil metal concentrations, and TF is the ratio of shoot/ root metal concentrations. Considering the fact that the total $\mathrm{Cd}, \mathrm{Pb}, \mathrm{Tl}$, and $\mathrm{Zn}$ concentrations can be extremely high in the post-mining sites, and BCF based on them could underestimate the ability of plants to transfer metals from the soil to the roots, EDTA-extractable metal-based $\mathrm{BCF}$ values $\left(\mathrm{BCF}_{\mathrm{EDTA}}\right)$ were also calculated for these elements.

The $\mathrm{BaCl}_{2}$-extractable $\mathrm{Fe}, \mathrm{Pb}$, and $\mathrm{Tl}$ were neither included in statistical analyses nor presented in tables, as most of the values were below the detection limits. Prior to statistical analyses, all variables were transformed with a logarithmic or exponential function and expressed on a 0-1 scale. Student's 
$t$ test and non-parametric Mann-Whitney's $U$ test were used to compare heap and control soils in terms of their physicochemical properties. Split-plot ANOVA was conducted to test the effect of plant species, the effect of plant organ (shoot vs. root), and the effect of species-organ interaction on element accumulation. This was followed by contrast analysis to estimate the differences in metal concentrations between the shoots and roots of particular species (Bonferroni correction for multiple comparisons was applied). Pearson's correlation coefficients were calculated to test the relationships between metal concentrations in the soil and plants. Statistical analyses were performed with Statistica 9 (StatSoft Inc.).

\section{Results}

\section{Physicochemical properties of the soil}

Total heavy metal concentrations in heap soils ranged from 8 to $337 \mathrm{mg} \mathrm{Cd} \mathrm{kg}^{-1}$, from 196 to $23006 \mathrm{mg} \mathrm{Pb} \mathrm{kg}^{-1}$, from 14 to $35 \mathrm{mg} \mathrm{Tl} \mathrm{kg}^{-1}$ and from 1126 to $42496 \mathrm{mg} \mathrm{Zn} \mathrm{kg}{ }^{-1}$, and were much higher than the concentrations in control soils (Table 1). The concentrations of mobile, i.e., $\mathrm{BaCl}_{2}$, EDTA-, or waterextractable $\mathrm{Cd}, \mathrm{Pb}$, and $\mathrm{Zn}$, but not $\mathrm{Tl}$, were also higher in the heap soils than in the control soils (Table 1). The variability of both total and available, i.e., $\mathrm{BaCl}_{2-}$, EDTA-, or waterextractable $\mathrm{Cd}, \mathrm{Pb}$ and $\mathrm{Zn}$, and $\mathrm{H}_{2} \mathrm{O}$-extractable $\mathrm{Tl}$, among the heap soils was high. The coefficients of variation $(\mathrm{CV})$ calculated for these parameters varied from 74 to $164 \%$, indicating a steep soil pollution gradient. In contrast, total and EDTA-extractable Tl was much less variable, with CV slightly exceeding $20 \%$. The concentrations of $\mathrm{Cd}, \mathrm{Pb}$, and $\mathrm{Zn}$ positively correlated with each other $(p<0.05$; correlation coefficients ranged from 0.50 to 0.96$)$, but not with $\mathrm{Tl}(p>0.05$; correlation coefficients ranged from 0.04 to 0.46 ). Significant positive correlations were found also between different forms of $\mathrm{Cd}, \mathrm{Pb}$, and $\mathrm{Zn}(p<0.05$; correlation coefficients varied from 0.73 to 0.96 ). Heap soils were similar to each other in terms of certain physicochemical properties. They were all alkaline and classified mostly as sandy loam. $\mathrm{CV}$ for $\mathrm{pH}$ and the contents of sand, silt and clay, alkali and alkaline earth metals, as well as $\mathrm{C}$ and $\mathrm{N}$ were relatively low, ranging from 3 to $73 \%$. Heap soils contained more C, N, Fe, Mg, Mn, and silt particles and had lower $\mathrm{pH}$ than the control soils (Table 1).

\section{Concentrations of elements in plants}

The concentrations of the pollution elements, i.e., $\mathrm{Cd}, \mathrm{Pb}, \mathrm{Tl}$, and $\mathrm{Zn}$, in the tissues of plants collected from heaps were high. They were on average 2.5-80 (Cd), 2.0-35 (Pb), 1.5-540 (Tl), and 2.7-20 ( $\mathrm{Zn})$ times higher than those determined for control plants (Table 2). The concentrations of heavy metals in heap plants were significantly $(p<0.05)$ affected by the plant species, plant organ (shoot vs. root) and the interaction of both factors. The pollution elements accumulated predominantly in roots; this was the most pronounced for $\mathrm{Pb}$ (Fig. 2a). The greatest amounts of $\mathrm{Cd}$ were found in the $P$. arenaria roots (on average $52 \mathrm{mg} \mathrm{kg}^{-1}$; Fig. 2b), $\mathrm{Pb}$ in the $F$. vesca roots (254 $\mathrm{mg} \mathrm{kg}^{-1}$; Fig. 2a), $\mathrm{Tl}$ in the $P$. lanceolata roots (23 $\mathrm{mg} \mathrm{kg}^{-1}$; Fig. 2c), and $\mathrm{Zn}$ in the $P$. arenaria roots (1479 $\mathrm{mg} \mathrm{kg}^{-1}$; Fig. 2d). A different pattern was observed for the concentration of $\mathrm{Tl}$ in the E. cyparissias tissues: it tended to be higher in the shoots than in the roots (10 vs. $2.1 \mathrm{mg} \mathrm{kg}^{-1}$; Fig. 2c). The difference was not statistically significant probably due to extreme inter-heap variability of $\mathrm{Tl}$ shoot concentrations: they were low $\left(<0.06 \mathrm{mg} \mathrm{kg}^{-1}\right)$ in plants from four heaps and high (5.4-44 $\mathrm{mg} \mathrm{kg}^{-1}$ ) in plants from three other locations. The accumulation of $\mathrm{Cd}, \mathrm{Pb}, \mathrm{Tl}$, and $\mathrm{Zn}$ in plant tissues differed considerably between sites (Table S1). The highest inter-heap variability was detected for $\mathrm{Tl}$, with CV often considerably exceeding $100 \%$. Very high variability was also found for $\mathrm{Pb}$, but only in the case of its root concentrations.

Heap plants tended to be impoverished in $\mathrm{Ca}, \mathrm{Fe}$, and $\mathrm{Mn}$ and enriched in $\mathrm{K}$ and $\mathrm{Mg}$ when compared to the control plants (Table 2). The concentrations of these elements in tissues were also significantly $(p<0.05)$ affected by the plant species, plant organ (shoot vs. root) and the interaction of both factors. The concentrations of macronutrients, i.e., $\mathrm{Ca}$ (Fig. 2e), K (Fig. 2f), and Mg (Fig. 2g), were generally higher in shoots than in roots or similar in the two organs, while the opposite was observed for Fe (Fig. 2h). The accumulation of $\mathrm{Mn}$ in plant organs did not follow any consistent pattern (Fig. 2i). The concentrations of $\mathrm{Ca}, \mathrm{Fe}, \mathrm{K}, \mathrm{Mg}$, and $\mathrm{Mn}$ varied among sites (Table S1), but the differences were generally smaller in comparison to those for $\mathrm{Pb}$ or $\mathrm{Tl}$. The lowest inter-heap variation was observed for macronutrients, whose CVs rarely exceeded $30 \%$.

\section{Bioconcentration (BCF) and translocation (TF) factors}

Bioconcentration factors $\left(\mathrm{BCF}_{\text {tot }}\right.$ and $\left.\mathrm{BCF}_{\mathrm{EDTA}}\right)$ differed between pollution elements and plant species (Table 3). They were generally $<1$ for $\mathrm{Cd}, \mathrm{Pb}$, and $\mathrm{Zn}$. As expected, the lowest values were found for $\mathrm{Pb}$, indicating very low level of $\mathrm{Pb}$ uptake by all species studied. In contrast, $\mathrm{BCF}_{\text {tot }}$ and $\mathrm{BCF}_{\mathrm{EDTA}}$ values for $\mathrm{Cd}$ and $\mathrm{Tl}$ were basically higher and more variable among species; $\mathrm{BCF}_{\mathrm{EDTA}}$ values for $\mathrm{Tl}$ were very high in all cases, suggesting efficient $\mathrm{Tl}$ uptake from soil (Table 3). Translocation factors were generally $<1$ for all pollution elements, which implies their restricted translocation from roots to shoots. TF values varied considerably among species, particularly in the case of $\mathrm{Tl}$ and $\mathrm{Cd}$ (Table 3).

$\mathrm{BCF}_{\text {tot }}$ values for $\mathrm{Ca}, \mathrm{Mg}$, and, particularly, $\mathrm{Fe}$, and $\mathrm{Mn}$ were low, contrasting with those for $\mathrm{K}$; the concentrations of $\mathrm{K}$ in plant tissues were a few times higher than those in soil 
Table 1 Physicochemical characteristics of the soil collected from old heaps and control sites

\begin{tabular}{|c|c|c|c|c|c|c|}
\hline & \multicolumn{3}{|c|}{ Heap soil $(N=18)$} & \multicolumn{3}{|c|}{ Control soil $(N=5)$} \\
\hline & minimum & mean $(\mathrm{SD})$ & maximum & minimum & mean $(\mathrm{SD})$ & maximum \\
\hline Sand $(\%)^{* *}$ & 45 & $61(10)$ & 84 & 70 & $81(10)$ & 96 \\
\hline Silt $(\%)(* *)$ & 7 & $21(7)$ & 30 & 2 & $6(3)$ & 11 \\
\hline Clay $(\%)$ & 7 & $17(9)$ & 38 & 2 & $13(8)$ & 23 \\
\hline $\mathrm{pH}^{* *}$ & 7.5 & $8.0(0.2)$ & 8.2 & 7.9 & $8.6(0.5)$ & 9.1 \\
\hline Organic C $(\%)^{*}$ & 1.2 & $3.3(1.4)$ & 6.7 & 0.1 & $1.5(2.0)$ & 4.9 \\
\hline Total N (\%)* & 0.15 & $0.25(0.07)$ & 0.42 & 0.02 & $0.13(0.15)$ & 0.39 \\
\hline Total $\mathrm{Ca}\left(\mathrm{g} \mathrm{kg}^{-1}\right)$ & 33 & $134(70)$ & 254 & 1 & $83(81)$ & 180 \\
\hline Total Cd $\left(\mathrm{mg} \mathrm{kg}^{-1}\right)(* * *)$ & 8 & $118(102)$ & 337 & 2 & $4(1)$ & 5 \\
\hline Total $\mathrm{Fe}\left(\mathrm{g} \mathrm{kg}^{-1}\right)^{* * *}$ & 8 & $41(26)$ & 102 & 1 & $8(4)$ & 13 \\
\hline Total $\mathrm{K}\left(\mathrm{g} \mathrm{kg}^{-1}\right)$ & 0.5 & $2.8(2.0)$ & 9.1 & 0.3 & $2.2(1.6)$ & 4.0 \\
\hline Total $\mathrm{Mg}\left(\mathrm{g} \mathrm{kg}^{-1}\right)(* * *)$ & 8.6 & 43.7 (21.6) & 76.9 & 0.2 & $2.5(1.5)$ & 3.8 \\
\hline Total Mn $\left(\mathrm{mg} \mathrm{kg}^{-1}\right)^{* * *}$ & 296 & $1168(766)$ & 3169 & 37 & $163(107)$ & 315 \\
\hline Total $\mathrm{Pb}\left(\mathrm{mg} \mathrm{kg}^{-1}\right)(* * *)$ & 196 & $3987(5354)$ & 23006 & 13 & $40(22)$ & 67 \\
\hline Total Tl $\left(\mathrm{mg} \mathrm{kg}^{-1}\right)^{* * *}$ & 14 & $25(6)$ & 35 & 1 & $10(8)$ & 17 \\
\hline Total $\mathrm{Zn}\left(\mathrm{mg} \mathrm{kg}^{-1}\right)(* * *)$ & 1126 & $18814(14698)$ & 42496 & 63 & $191(170)$ & 476 \\
\hline $\mathrm{BaCl}_{2}$-extractable $\mathrm{Ca}\left(\mathrm{g} \mathrm{kg}^{-1}\right)$ & 1.6 & $2.2(0.4)$ & 2.9 & 0.5 & $1.6(1.1)$ & 3.1 \\
\hline $\mathrm{BaCl}_{2}$-extractable $\mathrm{Cd}\left(\mathrm{mg} \mathrm{kg}^{-1}\right)(* *)$ & bdl & $4.7(4.9)$ & 14.7 & bdl & bdl & bdl \\
\hline $\mathrm{BaCl}_{2}$-extractable $\mathrm{K}\left(\mathrm{mg} \mathrm{kg}^{-1}\right)$ & 43 & $88(28)$ & 132 & 23 & $100(96)$ & 256 \\
\hline $\mathrm{BaCl}_{2}$-extractable $\mathrm{Mg}\left(\mathrm{mg} \mathrm{kg}^{-1}\right)(* * *)$ & 92 & $405(128)$ & 589 & 11 & $29(17)$ & 54 \\
\hline $\mathrm{BaCl}_{2}$-extractable $\mathrm{Mn}\left(\mathrm{mg} \mathrm{kg}^{-1}\right)^{* *}$ & 0.05 & $0.62(0.38)$ & 1.46 & 0.06 & $0.18(0.11)$ & 0.33 \\
\hline $\mathrm{BaCl}_{2}$-extractable $\mathrm{Zn}\left(\mathrm{mg} \mathrm{kg}^{-1}\right)(* * *)$ & 0.2 & $25.4(33.6)$ & 130.0 & bdl & $0.1(0.1)$ & 0.2 \\
\hline EDTA-extractable Cd $\left(\mathrm{mg} \mathrm{kg}^{-1}\right)(* * *)$ & 1.9 & $40.2(38.7)$ & 141.1 & 0.1 & $0.3(0.2)$ & 0.5 \\
\hline EDTA-extractable $\mathrm{Pb}\left(\mathrm{mg} \mathrm{kg}^{-1}\right)(* *)$ & 50 & $1268(2083)$ & 9092 & 6 & $18(21)$ & 56 \\
\hline EDTA-extractable $\mathrm{Tl}\left(\mathrm{mg} \mathrm{kg}^{-1}\right)$ & 1.0 & $1.4(0.3)$ & 2.0 & 0.3 & $1.3(0.7)$ & 1.8 \\
\hline EDTA-extractable $\mathrm{Zn}\left(\mathrm{mg} \mathrm{kg}^{-1}\right)(* * *)$ & 68 & $1489(1104)$ & 3673 & 3 & $6(3)$ & 10 \\
\hline water-extractable $\mathrm{Cd}\left(\mu \mathrm{g} \mathrm{kg}^{-1}\right)^{* * *}$ & 3 & $33(43)$ & 146 & 1 & $3(1)$ & 5 \\
\hline water-extractable $\mathrm{Pb}\left(\mu \mathrm{g} \mathrm{kg}^{-1}\right) * * *$ & 218 & $1319(1558)$ & 4609 & bdl & $41(32)$ & 83 \\
\hline water-extractable $\mathrm{Tl}\left(\mu \mathrm{g} \mathrm{kg}^{-1}\right)^{\mathrm{nd}}$ & bdl & $1.6(2.2)$ & 9.0 & nd & nd & nd \\
\hline water-extractable $\mathrm{Zn}\left(\mathrm{mg} \mathrm{kg}^{-1}\right)(* * *)$ & 1.1 & $7.5(6.6)$ & 27.8 & 0.2 & $0.4(0.1)$ & 0.5 \\
\hline
\end{tabular}

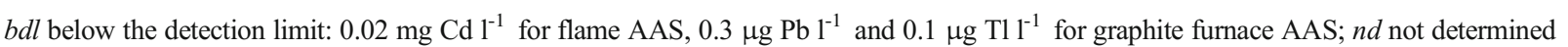
Asterisks indicate significant differences between the heap and control soil (Student's $t$ test: ${ }^{*} p<0.05,{ }^{*} p<0.01, * * * p<0.001$; Mann-Whitney's $U$ test: (*) $p<0.05,(* *) p<0.01,(* * *) p<0.001$

(Table 3). Ca, K, and Mg were easily transported to shoots, as indicated by $\mathrm{TF}$ values $>1$. TF values for Fe and Mn were $<1$ in most species; however, the reverse situation was quite frequent (Table 3).

\section{Concentrations of elements in plants in relation to soil}

The concentrations of $\mathrm{Cd}, \mathrm{Pb}$, and $\mathrm{Zn}$ in roots and shoots of nearly all species increased significantly with increasing metal concentration in soil (Table 4). The increase of $\mathrm{Cd}, \mathrm{Pb}$, and $\mathrm{Zn}$ in plant tissues was more pronounced for roots than shoots in most species (Fig. S1a for P. arenaria), but there were exceptions, in which the increase was similar in the above- and belowground organs (Fig. S1b for $H$. pilosella). The concentrations of $\mathrm{Cd}, \mathrm{Pb}$, and $\mathrm{Zn}$ in plant tissues generally reflected well the corresponding concentrations (both total and available, i.e., $\mathrm{BaCl}_{2^{-}}$, EDTA-, and water-extractable) of metals in the soil (Table 4). These relationships were quite strong; correlation coefficients (r) often exceeded 0.7 or even 0.8 . The relationships between the $\mathrm{Pb}$ content in the soil and plants were generally stronger for roots than for shoots, whereas patterns for $\mathrm{Cd}$ and $\mathrm{Zn}$ were more variable and depended on the plant species (Table 4). Soil-plant relationships for $\mathrm{Tl}$ were less consistent (Table 4). Total Mg was positively correlated to the $\mathrm{Mg}$ content in the shoots of $C$. hirta $(r=0.69), F$. vesca $(r=$ $0.82)$ and $P$. arenaria $(r=0.64)$, and in the roots of $F$. vesca $(r=$ 
Table 2 Ratios of average element concentrations in the heap plants to those in the control plants

\begin{tabular}{|c|c|c|c|c|c|c|c|c|c|c|c|}
\hline & & A. collina & C. hirta & E. cyparissias & F. vesca & H. pilosella & L. hispidus & P. arenaria & P. lanceolata & R. acetosa & S. ochroleuca \\
\hline \multirow[t]{2}{*}{$\mathrm{Ca}$} & shoot & 0.9 & 0.8 & 1.0 & 1.3 & 0.9 & 0.9 & 1.1 & 1.3 & 1.0 & 1.0 \\
\hline & root & 0.6 & 0.5 & 0.8 & 0.6 & 0.4 & 0.8 & 7.3 & 0.8 & 5.3 & 0.5 \\
\hline \multirow[t]{2}{*}{$\mathrm{Cd}$} & shoot & 28 & 5.9 & 14 & 9.1 & 37 & 3.2 & 9.6 & 6.0 & 2.5 & 2.9 \\
\hline & root & 21 & 9.6 & 80 & 29 & 31 & 15 & 43 & 37 & 6.5 & 46 \\
\hline \multirow[t]{2}{*}{$\mathrm{Fe}$} & shoot & 0.5 & 0.9 & 0.5 & 1.9 & 1.1 & 0.8 & 2.3 & 0.7 & 0.9 & 0.8 \\
\hline & root & 0.3 & 0.8 & 0.8 & 0.6 & 0.7 & 0.6 & 0.9 & 0.8 & 0.8 & 0.7 \\
\hline \multirow[t]{2}{*}{ K } & shoot & 1.4 & 1.4 & 1.6 & 1.9 & 1.3 & 1.3 & 1.1 & 1.5 & 1.3 & 1.3 \\
\hline & root & 0.8 & 0.9 & 1.1 & 1.1 & 1.0 & 0.9 & 1.0 & 1.1 & 1.0 & 0.9 \\
\hline \multirow[t]{2}{*}{$\mathrm{Mg}$} & shoot & 1.8 & 1.7 & 2.2 & 2.9 & 2.5 & 1.4 & 3.2 & 2.5 & 1.5 & 1.5 \\
\hline & root & 1.9 & 1.3 & 1.6 & 1.8 & 2.4 & 1.2 & 1.7 & 1.4 & 1.2 & 1.8 \\
\hline \multirow[t]{2}{*}{$\mathrm{Mn}$} & shoot & 0.3 & 1.0 & 0.7 & 0.8 & 1.0 & 0.6 & 1.6 & 0.6 & 0.5 & 0.7 \\
\hline & root & 0.5 & 0.6 & 1.0 & 0.5 & 0.8 & 0.7 & 2.4 & 0.4 & 0.5 & 0.6 \\
\hline \multirow[t]{2}{*}{$\mathrm{Pb}$} & shoot & 2.5 & 3.3 & 3.4 & 2.7 & 2.0 & 2.9 & 3.5 & 3.3 & 10 & 3.1 \\
\hline & root & 14 & 12 & 35 & 14 & 4.7 & 16 & 11 & 18 & 19 & 17 \\
\hline \multirow[t]{2}{*}{$\mathrm{Tl}$} & shoot & 8.7 & 1.5 & 268 & 5.9 & 3.6 & 8.0 & 5.2 & 124 & 8.8 & 9.1 \\
\hline & root & 418 & 44 & 109 & 59 & 56 & 427 & 77 & 424 & 44 & 540 \\
\hline \multirow[t]{2}{*}{$\mathrm{Zn}$} & shoot & 4.0 & 2.7 & 8.3 & 5.9 & 5.6 & 10 & 5.1 & 5.0 & 9.3 & 7.2 \\
\hline & root & 14 & 7.2 & 18 & 20 & 7.9 & 18 & 7.9 & 12 & 13 & 16 \\
\hline
\end{tabular}

Ratios $<1$ are given in italics. A. collina ( $N=7$ and 3 for heap and control plants, respectively), C. hirta ( $N=18$ and 3), E. cyparissias ( $N=7$ and 3$), F$. vesca $(N=18$ and 2$), H$. pilosella $(N=18$ and 2$)$, L. hispidus $(N=7$ and 2), P. arenaria $(N=18$ and 1$), P$. lanceolata $(N=18$ and 3$), R$. acetosa $(N=7$ and 2$)$, S. ochroleuca $(N=7$ and 3$)$

0.62), P. arenaria $(r=0.56)$, and $P$. lanceolata $(r=0.48)$, while $\mathrm{BaCl}_{2}$-extractable $\mathrm{Mg}$ was correlated with the $\mathrm{Mg}$ content in the shoots $(r=0.57)$ and roots of $F$. vesca $(r=0.51)$. Significant soil-plant correlations for other elements, i.e., $\mathrm{Ca}, \mathrm{Fe}, \mathrm{K}$, and Mn, were sporadic or non-existent.

\section{Discussion}

The concentrations of $\mathrm{Cd}, \mathrm{Pb}, \mathrm{Tl}$, and $\mathrm{Zn}$ were elevated in the soil from old heaps, reaching sometimes extreme levels. These concentrations were much higher than those reported typically for unpolluted soils, while they were similar to the values measured at other sites affected by metal ore mining and processing (Kabata-Pendias 2011). Soils that had developed on old heaps were also rich in total $\mathrm{Fe}$ and $\mathrm{Mn}$ in comparison to control soils, which results from the presence of Fe sulfides or sulfates as well as $\mathrm{Mn}$ and $\mathrm{Fe}$ oxides in $\mathrm{Zn}-\mathrm{Pb}$ ores (Cabala et al. 2009). According to Kabata-Pendias (2011). similar or even higher amounts of $\mathrm{Mn}$ are found in some nonmetalliferous (calcareous) soils. The heap soils were also characterized by high concentrations of $\mathrm{Mg}$ and $\mathrm{Ca}$, which originated from the weathering of gangue carbonates - dolomite and calcite (Cabala et al. 2009; Stefanowicz et al. 2014).

The concentrations of the main pollutants, i.e., $\mathrm{Cd}, \mathrm{Pb}, \mathrm{Tl}$, and $\mathrm{Zn}$, in the tissues of plants growing on heaps were much higher than values for the "reference plant" introduced by
Markert (1992). i.e., $0.05 \mathrm{mg} \mathrm{Cd} \mathrm{kg}{ }^{-1}, 1 \mathrm{mg} \mathrm{Pb} \mathrm{kg}{ }^{-1}$, $0.05 \mathrm{mg} \mathrm{Tl} \mathrm{kg}^{-1}$, and $50 \mathrm{mg} \mathrm{Zn} \mathrm{kg}{ }^{-1}$. Heap plants contained much more $\mathrm{Cd}, \mathrm{Pb}, \mathrm{Tl}$, and $\mathrm{Zn}$ than controls, reaching levels typical for plants from the areas of metal mining and processing (Godzik 1993; Kabata-Pendias 2011; Xiao et al. 2004). As expected, metal concentrations differed between the plant species and plant organs. The highest concentrations of $\mathrm{Cd}, \mathrm{Pb}$, and $\mathrm{Zn}$ were detected in the roots of E. cyparissias, $F$. vesca, $P$. arenaria, $P$. lanceolata, and $S$. ochroleuca, whereas $\mathrm{Tl}$ in the roots of $P$. lanceolata and $S$. ochroleuca. Of these plants, $P$. lanceolata has often been tested for its ability to accumulate heavy metals: the tissue concentrations of $\mathrm{Cd}, \mathrm{Pb}, \mathrm{Tl}$, and $\mathrm{Zn}$ in this study were largely similar to the concentrations reported by Abe et al. (2008). Álvarez-Ayuso et al. (2013). Nadgórska-Socha et al. (2013). Orłowska et al. (2002) and Wójcik et al. (2014). but markedly lower than those reported by Wierzbicka et al. (2004) or Dimitrova and Yurukova (2005). Concentrations of $\mathrm{Cd}, \mathrm{Pb}$, or $\mathrm{Zn}$ in the shoots of C. hirta, H. pilosella, L. hispidus, P. arenaria, R. acetosa, and $S$. ochroleuca growing on old heaps were consistent with the concentrations measured by Turnau et al. (2010) and Wójcik et al. (2014) in plants from metal-polluted areas.

Average Fe concentrations in both heap and control plants oscillated around the reference value $\left(150 \mathrm{mg} \mathrm{kg}^{-1}\right.$; Markert 1992) and generally fell within the ranges found naturally in plants (Kabata-Pendias 2011). Fe concentrations in the heap plants were broadly similar to those given by Godzik (1993). 
Fig. 2 Comparison of element accumulation levels between plant species growing on the heaps left by historical $\mathrm{Zn}-\mathrm{Pb}$ ore mining (means and standard errors, $N=7)$. Statistically significant differences in the element accumulation between plant organs are asterisked: ${ }^{*} p<0.005$, Bonferroni correction applied; $(*) 0.005<p<0.05$
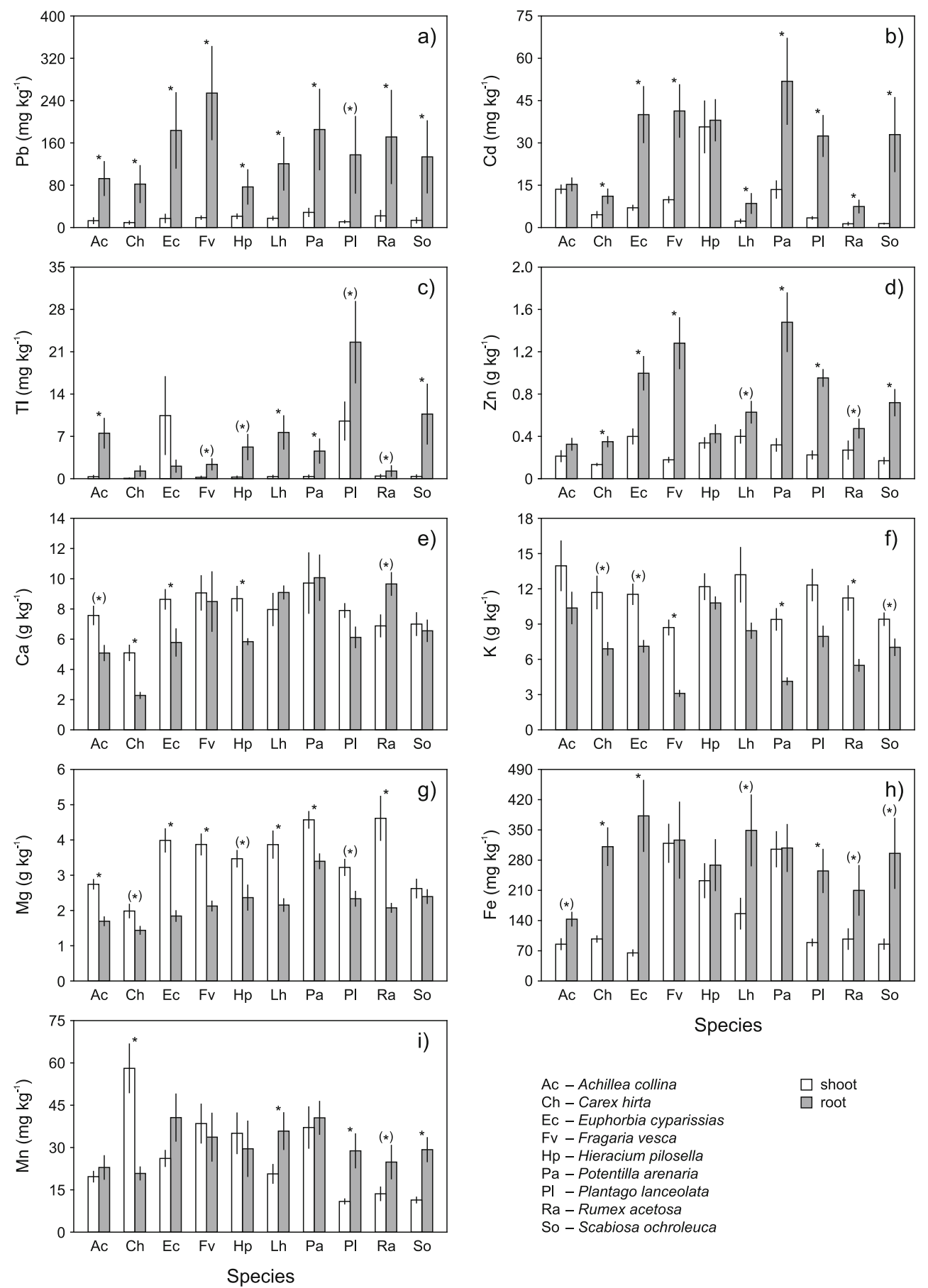

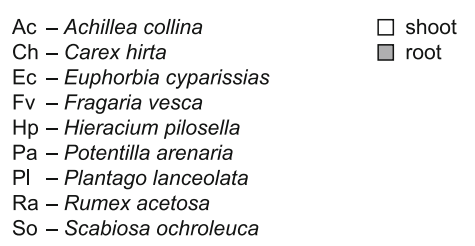

Ec - Euphorbia cyparissia

Fv - Fragaria vesca

$\mathrm{Hp}$ - Hieracium pilosella

PI - Plantago lanceolata

So - Scabiosa ochroleuca but several times lower than some of the values reported by other authors. For example, $H$. pilosella growing on tailings accumulated on average $1500 \mathrm{mg} \mathrm{Fe} \mathrm{kg}{ }^{-1}$ in the leaves (Turnau et al. 2010). P. lanceolata from calamine spoils over $1000 \mathrm{mg} \mathrm{kg}^{-1}$ in roots (Szarek-Łukaszewska and Niklińska 2002), and $F$. vesca from slags up to $1700 \mathrm{mg} \mathrm{kg}^{-1}$ (Antosiewicz et al. 2008).

The concentrations of $\mathrm{Mn}$ were low in the old heap and control plants in comparison to the "reference plant" (200 $\mathrm{mg} \mathrm{kg}^{-1}$; Markert 1992). The lowest average Mn concentrations were detected in P. lanceolata, S. ochroleuca, and $R$. acetosa; values for these species were lower than 15 $25 \mathrm{mg} \mathrm{Mn} \mathrm{kg}^{-1}$, which is considered as the critical deficiency level for most plants (Kabata-Pendias 2011). Moreover, the $\mathrm{Fe} / \mathrm{Mn}$ ratio was $>2.5$ for $80 \%$ of the plant shoot samples from the heap and control sites (data not shown), reaching in many cases very high values; this also indicated Mn deficiency (Kabata-Pendias 2011). Mn and Fe are interrelated in metabolic functions and the $\mathrm{Fe} / \mathrm{Mn}$ tissue ratio between 1.5 and 2.5 is necessary for a plant to be healthy (Kabata-Pendias 


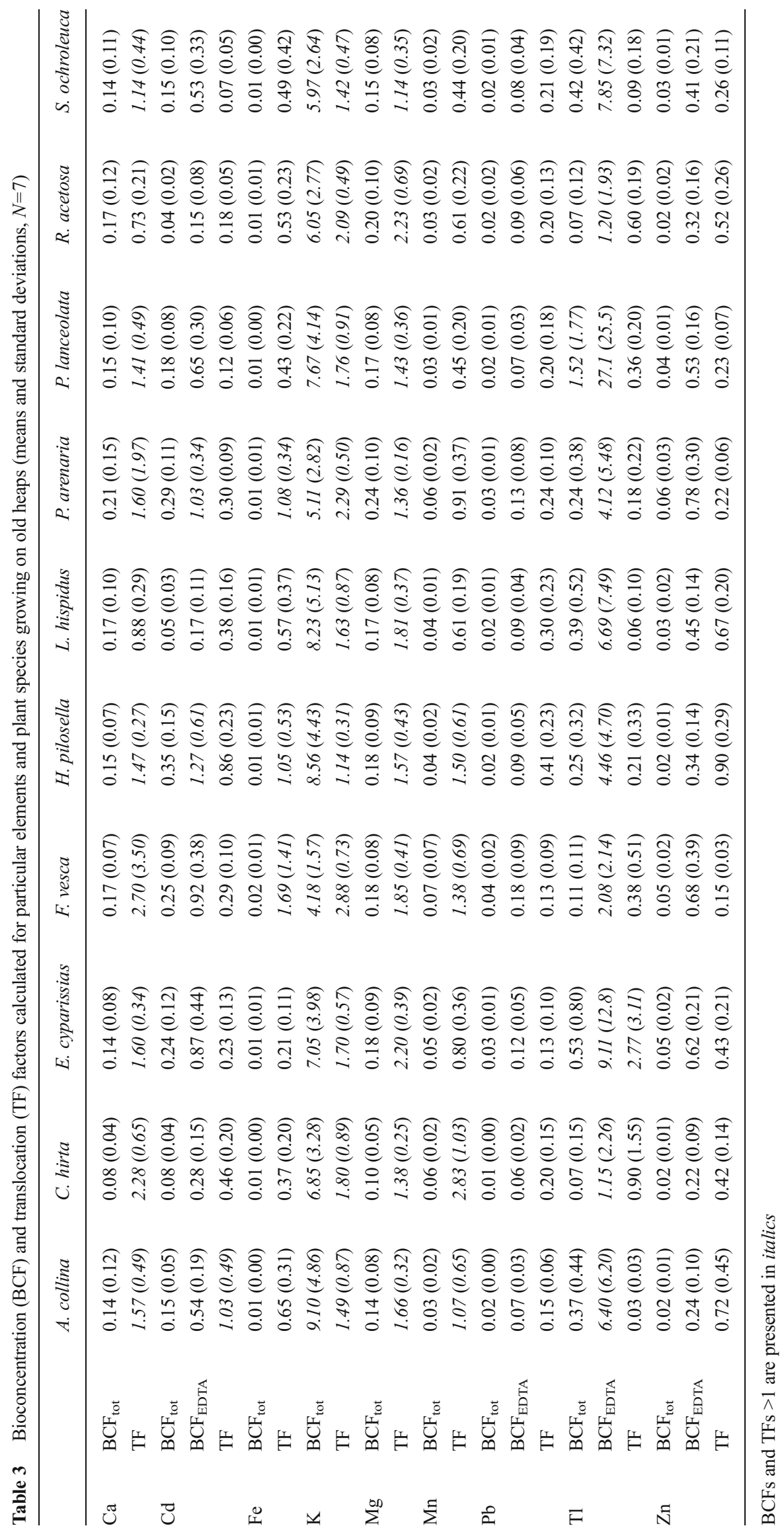


Table 4 Correlations between heavy metals in soil and plant tissues $(N=18)$

\begin{tabular}{|c|c|c|c|c|c|c|c|c|c|c|c|}
\hline & & \multicolumn{2}{|l|}{ C. hirta } & \multicolumn{2}{|l|}{ F. vesca } & \multicolumn{2}{|c|}{ H. pilosella } & \multicolumn{2}{|c|}{ P. arenaria } & \multicolumn{2}{|c|}{ P. lanceolata } \\
\hline & & shoot & root & shoot & root & shoot & root & shoot & root & shoot & root \\
\hline \multirow[t]{4}{*}{$\mathrm{Cd}$} & Total & $0.51 *$ & $0.67 * *$ & $0.87 * * *$ & $0.82 * * *$ & $0.76^{* * *}$ & $0.79 * * *$ & $0.89 * * *$ & $0.89 * * *$ & $0.53 *$ & $0.84 * * *$ \\
\hline & EDTA-extractable & $0.59 *$ & $0.67 * *$ & $0.78^{* * *}$ & $0.74 * * *$ & $0.73^{* * *}$ & $0.74 * * *$ & $0.86^{* * *}$ & $0.86^{* * *}$ & $0.61 * *$ & $0.87 * * *$ \\
\hline & $\mathrm{BaCl}_{2}$-extractable & $0.53 *$ & $0.73 * * *$ & $0.85^{* * *}$ & $0.77 * * *$ & $0.81 * * *$ & $0.83 * * *$ & $0.82 * * *$ & $0.79 * * *$ & $0.57 *$ & $0.83^{* * *}$ \\
\hline & $\mathrm{H}_{2} \mathrm{O}$-extractable & $0.64 * *$ & $0.71 * *$ & $0.68 * *$ & $0.68 * *$ & $0.72 * * *$ & $0.71 * *$ & $0.67 * *$ & $0.71 * * *$ & $0.72 * * *$ & $0.74 * * *$ \\
\hline \multirow[t]{3}{*}{$\mathrm{Pb}$} & Total & $0.57 *$ & $0.85^{* * *}$ & $0.63 * *$ & $0.86^{* * *}$ & $0.67 * *$ & $0.74 * * *$ & $0.55^{*}$ & $0.65^{* *}$ & $0.58 *$ & $0.80 * * *$ \\
\hline & EDTA-extractable & $0.59 * *$ & $0.86^{* * *}$ & $0.64 * *$ & $0.85^{* * *}$ & $0.63 * *$ & $0.68^{* *}$ & $0.59 *$ & $0.64 * *$ & $0.66^{* *}$ & $0.86^{* * *}$ \\
\hline & $\mathrm{H}_{2} \mathrm{O}$-extractable & $0.59^{*}$ & $0.79 * * *$ & $0.56^{*}$ & $0.67 * *$ & ns & $0.55^{*}$ & ns & ns & ns & $0.70 * *$ \\
\hline \multirow[t]{3}{*}{$\mathrm{Tl}$} & Total & ns & ns & ns & ns & ns & ns & ns & ns & ns & ns \\
\hline & EDTA-extractable & ns & ns & $0.52 *$ & ns & ns & ns & ns & ns & ns & ns \\
\hline & $\mathrm{H}_{2} \mathrm{O}$-extractable & $0.66^{* *}$ & $0.49 *$ & $0.66^{* *}$ & ns & $0.57^{*}$ & ns & $0.55 *$ & ns & ns & ns \\
\hline \multirow[t]{4}{*}{$\mathrm{Zn}$} & Total & ns & $0.69 * *$ & $0.65^{* *}$ & $0.75^{* * *}$ & $0.74 * * *$ & $0.68 * *$ & $0.72 * * *$ & $0.82 * * *$ & $0.66^{* *}$ & $0.75^{* * *}$ \\
\hline & EDTA-extractable & ns & $0.68 * *$ & $0.63 * *$ & $0.68 * *$ & $0.78 * * *$ & $0.61 * *$ & $0.79 * * *$ & $0.82 * * *$ & $0.75^{* * *}$ & $0.85^{* * *}$ \\
\hline & $\mathrm{BaCl}_{2}$-extractable & ns & $0.74 * * *$ & $0.58 *$ & $0.66^{* *}$ & $0.64 * *$ & $0.53 *$ & $0.73 * * *$ & $0.78 * * *$ & $0.67 * *$ & $0.78^{* * *}$ \\
\hline & $\mathrm{H}_{2} \mathrm{O}$-extractable & ns & $0.59 * *$ & $0.53 *$ & $0.70 * *$ & $0.70^{* *}$ & $0.64 * *$ & ns & $0.60 * *$ & $0.60 * *$ & $0.63 * *$ \\
\hline
\end{tabular}

$* * * p<0.001, * * p<0.01,{ }^{*} p<0.05$

$n s$ not significant

2011). High Fe/Mn tissue ratios detected in this study suggests that the Fe deficiency could be expected neither in control nor in the heap plants, although $\mathrm{Fe}$, like $\mathrm{Mn}$, is poorly available in the well-oxidized neutral and alkaline soils (Lambers et al. 2008; Kabata-Pendias 2011).

The concentrations of $\mathrm{Ca}$ and $\mathrm{Mg}$ in plant tissues from the heap and control sites generally fell within the range typical for plants not exposed to stress, i.e., $1-44 \mathrm{~g} \mathrm{Ca} \mathrm{kg}^{-1}$ and 1-4 $\mathrm{g} \mathrm{Mg} \mathrm{kg}^{-1}$ (Bose et al. 2011; Broadley et al. 2003) and varied around the reference values, i.e., $10 \mathrm{~g} \mathrm{Ca} \mathrm{kg}^{-1}$ and $2 \mathrm{~g} \mathrm{Mg} \mathrm{kg}^{-1}$ (Markert 1992). The concentrations of $\mathrm{K}$ in both heap and control plants were below or near the lower limit of the normal range observed in plants, i.e., $10-100 \mathrm{~g} \mathrm{~kg}^{-1}$ (Britto and Kronzucker 2008) and were generally lower than the $\mathrm{K}$ concentration of the "reference plant" (19 $\mathrm{g} \mathrm{kg}^{-1}$; Markert 1992). According to expectations, the concentrations of $\mathrm{Ca}, \mathrm{K}$, and $\mathrm{Mg}$ seemed to differ between the heap and control plants. $\mathrm{Ca}, \mathrm{Fe}$, and $\mathrm{Mn}$ tended to be lower, while $\mathrm{K}$ and $\mathrm{Mg}$ were higher in the heap than in control plants. These findings are somewhat surprising, as the concentrations of available $\left(\mathrm{BaCl}_{2}\right.$-extractable) forms of $\mathrm{Ca}, \mathrm{Fe}, \mathrm{K}$, and $\mathrm{Mn}$ were either higher in the heap than in control or similar in the two soils. Our results are in contrast with Turnau et al. (2010) who found that many plant species growing on post-flotation wastes contained more $\mathrm{Fe}$ and $\mathrm{Ca}$ in the leaves than control plants, although the availability of these elements in the waste was low. The opposite was observed for $\mathrm{K}$-its concentrations were generally lower in plants from tailings, but this probably resulted from a lower availability of this element at that site (Turnau et al. 2010). Evident enrichment of heap plant tissues in $\mathrm{Mg}$ detected in our study resulted probably from the higher $\mathrm{Mg}$ concentration and availability in heap soils, originating from the high dolomite content in the waste. Godzik (1993) often reported more $\mathrm{Fe}$ and $\mathrm{Mg}$ in the heap plants, but the accumulation of these elements and $\mathrm{Ca}$ in the heap and control plants depended on the species and organ. Patterns of element accumulation in plants depend on the availability of a given element in the soil, plant physiology, and complex interactions between elements, particularly in the heavy-metal rich environments. Heavy metals may cause disturbances in the $\mathrm{K} / \mathrm{Ca}$ ratio in plant tissues, followed by alterations in the water balance, and Fe deficiency due to decreased uptake or immobilization in the roots (Siedlecka 1995). Cd may replace Mn during the uptake process, whereas the $\mathrm{Fe}-\mathrm{Ca}$ interaction suppresses Fe availability (Kabata-Pendias 2011). Goss and Carvalho (1992) reported that the maximum Mn concentration in shoots fell as the concentration of $\mathrm{Mg}$ in the nutrient solution increased; $\mathrm{Mg}$ also reduced the quantity of $\mathrm{Mn}$ translocated from the roots. Changes in the tissue concentrations of some nutrients in plants growing in heavy metal-polluted soil may result from the competition for uptake between cations that have similar ionic radii (Siedlecka 1995). Antosiewicz (2005) claimed that the inhibition of $\mathrm{Ca}$ channels in a cell may result either from the competitive transport or from channel blockage by $\mathrm{Pb}$. The uptake of $\mathrm{Ca}, \mathrm{Fe}$, or $\mathrm{Mn}$ by roots may be decreased if the roots are damaged or their growth is inhibited by heavy metals (Godbold and Kettner 1991; Ouzounidou et al. 
1995; Siedlecka 1995). Heavy metals may cause root membrane lipid peroxidation, damaging the permeability barrier of root cells, influence the activity of ATP-ases and other carriers, as well as decrease root respiration, which may reduce the uptake of elements actively transported into the roots (De Vos et al. 1991; Ros et al. 1992; Siedlecka 1995).

The efficiency of element acquisition and accumulation in plant tissues differed considerably between the elements, plant species, and organs (shoots vs. roots). K was taken up from the soil quite efficiently and all macronutrients were effectively translocated to shoots. In contrast, $\mathrm{Cd}, \mathrm{Pb}, \mathrm{Tl}$, and $\mathrm{Zn}$ were accumulated mainly in roots; the restricted translocation to the shoots was most noticeable for $\mathrm{Pb}$, which is a well-known phenomenon (Kabata-Pendias 2011; Siedlecka 1995). Plant species that have evolved both tolerant and non-tolerant ecotypes, such as species tested in this study, often behave as excluders - plants that restrict heavy metal transport from roots to shoots (Baker 1981; Pollard et al. 2002).

Inter-heap variability in metal accumulation of individual species was high, which might be the result of both soil- and population-specific properties (Kabata-Pendias 2011; Pošćić et al. 2013). An interesting observation was made in this study for E. cyparissias; its populations largely differed in the $\mathrm{Tl}$ root-shoot translocation. The concentration of $\mathrm{H}_{2} \mathrm{O}$-extractable $\mathrm{Tl}$ explained well the variation in $\mathrm{Tl}$ concentration in the shoots and roots of E. cyparissias, but not the variation in TF (data not shown). Tl translocation may be populationspecific, as different populations may have different $\mathrm{Tl}$ accumulation strategies. It has been already shown for Biscutella laevigata that the ability to hyperaccumulate $\mathrm{Tl}$ is not a species-wide property (Pošćić et al. 2013). More work is needed, including extensive sampling of E. cyparissias populations in the field and their cultivation under controlled conditions, to elucidate the differences in the $\mathrm{Tl}$ translocation in this plant species.

The concentrations of $\mathrm{Cd}, \mathrm{Pb}$, and $\mathrm{Zn}$ in plant tissues were mainly positively related to their concentrations in the soil. These findings are in agreement with observations described by other authors, albeit soil-plant relationships may depend on a metal itself, metal extraction from the soil, soil type, or plant species (Chojnacka et al. 2005; Deng et al. 2004; KabataPendias 2011). Deng et al. (2004) claimed that metals in the underground tissues generally had stronger positive correlations with metals in the substratum than the aboveground tissues. It was also often observed in our study, being particularly pronounced for $\mathrm{Pb}$. Significant soil-plant correlations for $\mathrm{Ca}$, $\mathrm{Fe}, \mathrm{K}, \mathrm{Mg}, \mathrm{Mn}$, and $\mathrm{Tl}$ were less frequently observed. This may be explained in part by the inter-heap variation in the concentrations of soil elements, which was generally high for all forms of $\mathrm{Cd}, \mathrm{Pb}$ and $\mathrm{Zn}$, and low for other elements. Large variation in metal concentrations facilitates the detection of soil-plant relationships.

\section{Conclusions}

Old heaps left by historical mining for $\mathrm{Zn}-\mathrm{Pb}$ ores are "hot spots" of heavy metal contamination, and thus affect neighboring agricultural land and possibly pose a threat to the environment and people (Stefanowicz et al. 2014). This study proved that plants overgrowing old heaps accumulate much higher amounts of $\mathrm{Cd}, \mathrm{Pb}, \mathrm{Tl}$, and $\mathrm{Zn}$ than the plants from control sites. The highest contents of heavy metals were found in the roots, but their levels in the shoots were elevated as well, implying a risk of transport of toxicants along the food chain. Considering the fact that old heaps frequently occur near human settlements, arable fields, and vegetable gardens, and that the dolomite waste rock, which forms the heaps, is sometimes collected and re-used by local residents for different purposes, e.g., to level the ground around their homes, small-scale crop production on these vast post-mining areas may be hazardous (Stefanowicz et al. 2014).

From among the ten plant species tested in our study, F. vesca, P. arenaria, P. lanceolata, and S. ochroleuca seem to be the most suitable for reclamation of metal-polluted areas. They accumulate high amounts of heavy metals in the roots and have a relatively high (although basically $<1$ ) plant/soil ratio as well as relatively low shoot/root ratio, so they can be useful in phytostabilization. These species are components of naturally valuable xerothermic grasslands that develop spontaneously in metal-polluted areas and may be potentially used in directed succession.

Acknowledgments The authors wish to thank Elżbieta Chrzanowska, Stanisław Braniewski, and Urszula Korzeniak for their valuable assistance in laboratory work. Irena M. Grześ is acknowledged for her comments on an earlier version of the manuscript. The study was financially supported by the Ministry of Science and Higher Education (grants for young scientists and $\mathrm{PhD}$ students 4604/E-37/M/2012) and the National Science Centre (N N305 018040) of the Republic of Poland. The W. Szafer Institute of Botany, Polish Academy of Sciences also provided partial funding.

Open Access This article is distributed under the terms of the Creative Commons Attribution 4.0 International License (http:// creativecommons.org/licenses/by/4.0/), which permits unrestricted use, distribution, and reproduction in any medium, provided you give appropriate credit to the original author(s) and the source, provide a link to the Creative Commons license, and indicate if changes were made.

\section{References}

Abe T, Fukami M, Ogasawara M (2008) Cadmium accumulation in the shoots and roots of 93 weed species. Soil Sci Plant Nutr 54:566-573

Adams R, Ahlfeld D, Sengupta A (2007) Investigating the potential for ongoing pollution from an abandoned pyrite mine. Mine Water Environ 26:2-13

Aleksander-Kwaterczak U, Ciszewski D (2013) Soil contamination at the historical $\mathrm{Zn}-\mathrm{Pb}$ ore mining sites (Southern Poland). E3S Web of Conferences 1, 19001. doi:10.1051/e3sconf/2013119001 
Álvarez-Ayuso E, Otones V, Murciego A, García-Sánchez A, Santa Regina I (2013) Zinc, cadmium and thallium distribution in soils and plants of an area impacted by sphalerite-bearing mine wastes. Geoderma 207-208:25-34

Antosiewicz DM (2005) Study of calcium-dependent lead-tolerance on plants differing in their level of Ca-deficiency tolerance. Environ Pollut 134:23-34

Antosiewicz DM, Escudě-Duran C, Wierzbowska E, Skłodowska A (2008) Indigenous plant species with the potential for the phytoremediation of arsenic and metals contaminated soil. Water Air Soil Pollut 193:197-210

Baker AJM (1981) Accumulators and excluders - strategies in the response of plants to heavy metals. J Plant Nutr 3:643-654

Bose J, Babourina O, Rengel Z (2011) Role of magnesium in alleviation of aluminium toxicity in plants. J Exp Bot 62:2251-2264

Britto DT, Kronzucker HJ (2008) Cellular mechanisms of potassium transport in plants. Physiol Plant 133:637-650

Broadley MR, Bowen HC, Cotterill HL, Hammond JP, Meacham MC, Mead A, White PJ (2003) Variation in the shoot calcium content of angiosperms. J Exp Bot 54:1431-1446

Cabala J, Krupa P, Misz-Kennan M (2009) Heavy metals in mycorrhizal rhizospheres contaminated by $\mathrm{Zn}-\mathrm{Pb}$ mining and smelting around Olkusz in Southern Poland. Water Air Soil Pollut 199:139-149

Chojnacka K, Chojnacki A, Górecka H, Górecki H (2005) Bioavailability of heavy metals from polluted soils to plants. Sci Total Environ 337: $175-182$

Dahmani-Muller H, van Oort F, Gélie B, Balabane M (2000) Strategies of heavy metal uptake by three plant species growing near a metal smelter. Environ Pollut 109:231-238

De Vos CHR, Schat H, De Waal MAM, Vooijs R, Ernst WHO (1991) Increased resistance to copper-induced damage of the root cell plasmalemma in copper tolerant Silene cucubalus. Physiol Plant 82:523-528

Deng H, Ye ZH, Wong MH (2004) Accumulation of lead, zinc, copper and cadmium by 12 wetland plant species thriving in metalcontaminated sites in China. Environ Pollut 132:29-40

Dimitrova I, Yurukova L (2005) Bioindication of anthropogenic pollution with Plantago lanceolata (Plantaginaceae): metal accumulation, morphological and stomatal leaf characteristics. Phytol Balc 11:89-96

Eckel WP, Rabinowitz MB, Foster GD (2001) Discovering unrecognized lead-smelting sites by historical methods. Am J Public Health 91: 625-627

Godbold DL, Kettner C (1991) Lead influences root growth and mineral nutrition of Picea abies seedlings. J Plant Physiol 139:95-99

Godzik B (1993) Heavy metals content in plants from zinc dumps and reference areas. Polish Bot Stud 5:113-132

Goss MJ, Carvalho MJGPR (1992) Manganese toxicity: the significance of magnesium for the sensitivity of wheat plants. Plant Soil 139:91-98

Grattan JP, Huxley SI, Pyatt FB (2003) Modern Bedouin exposures to copper contamination: an imperial legacy? Ecotoxicol Environ Saf $55: 108-115$

Harrison J, Heijnis H, Caprarelli G (2003) Historical pollution variability from abandoned mine sites, Greater Blue Mountains World Heritage Area, New South Wales, Australia. Environ Geol 43:680-687

Kabata-Pendias A (2011) Trace elements in soils and plants. CRC Press Taylor\&Francis Group, Boca Raton London New York

Lambers H, Chapin FS III, Pons TL (2008) Plant physiological ecology. Springer Science + Business Media, LLC, New York

Markert B (1992) Establishing of "reference plant" for inorganic characterization of different plant species by chemical fingerprinting. Water Air Soil Pollut 64:533-538

Mertens J, Luyssaert S, Verheyen K (2005) Use and abuse of trace metal concentrations in plant tissue for biomonitoring and phytoextraction. Environ Pollut 138:1-4

Nadgórska-Socha A, Ptasiński B, Kita A (2013) Heavy metal bioaccumulation and antioxidative responses in Cardaminopsis arenosa and
Plantago lanceolata leaves from metalliferous and nonmetalliferous sites: a field study. Ecotoxicology 22:1422-1434

Orłowska E, Zubek S, Jurkiewicz A, Szarek-Łukaszewska G, Turnau K (2002) Influence of restoration on arbuscular mycorrhiza of Biscutella laevigata L. (Brassicaceae) and Plantago lanceolata L. (Plantaginaceae) from calamine spoil mounds. Mycorrhiza 12:153-159

Ouzounidou G, Čiamporová M, Moustakas M, Karataglis S (1995) Responses of maize (Zea mays L.) plants to copper stress-I. Growth, mineral content and ultrastructure of roots. Environ Exp Bot 35:167-176

Peralta-Videa JR, Lopez ML, Narayan M, Saupe G, Gardea-Torresdey J (2009) The biochemistry of environmental heavy metal uptake by plants: implications for the food chain. Int J Biochem Cell Biol 41: 1665-1677

Pollard AJ, Powell KD, Harper FA, Smith JAC (2002) The genetic basis of metal hyperaccumulation in plants. Crit Rev Plant Sci 21:539-566

Pollard AJ, Reeves RD, Baker AJM (2014) Facultative hyperaccumulation of heavy metals and metalloids. Plant Sci 217-218:8-17

Pošćić F, Marchiol L, Schat H (2013) Hyperaccumulation of thallium is population-specific and uncorrelated with caesium accumulation in the thallium hyperaccumulator, Biscutella laevigata. Plant Soil 365: $81-91$

Pyatt FB, Gilmore G, Grattan JP, Hunt CO, McLaren S (2000) An imperial legacy? An exploration of the environmental impact of ancient metal mining and smelting in southern Jordan. J Archaeol Sci 27:771778

Pyatt FB, Pyatt AJ, Walker C, Sheen T, Grattan JP (2005) The heavy metal content of skeletons from an ancient metalliferous polluted area in southern Jordan with particular reference to bioaccumulation and human health. Ecotoxicol Environ Saf 60:295-300

Ros R, Morales A, Segura J, Picazo I (1992) In vivo and in vitro effects of nickel and cadmium on the plasmalemma ATPase from rice (Oryza sativa L.) shoots and roots. Plant Sci 83:1-6

Siedlecka A (1995) Some aspects of interactions between heavy metals and plant mineral nutrients. Acta Soc Bot Pol 64:265-272

Stefanowicz AM, Woch MW, Kapusta P (2014) Inconspicuous waste heaps left by historical $\mathrm{Zn}-\mathrm{Pb}$ mining are hot spots of soil contamination. Geoderma 235-236:1-8

Szarek-Łukaszewska G, Niklińska M (2002) Concentration of alkaline and heavy metals in Biscutella laevigata $\mathrm{L}$. and Plantago lanceolata L. growing on calamine spoils (S. Poland). Acta Biol Cracov Ser Bot 44:29-38

Tatsi K, Turner A (2014) Distributions and concentrations of thallium in surface waters of a region impacted by historical metal mining (Cornwall, UK). Sci Total Environ 473-474:139-146

Teršič T, Gosar M, Šajn R (2009) Impact of mining activities on soils and sediments at the historical mining area in Podljubelj, NW Slovenia. J Geochem Explor 100:1-10

Turnau K, Ostachowicz B, Wojtczak G, Anielska T, Sobczyk Ł (2010) Metal uptake by xerothermic plants introduced into $\mathrm{Zn}-\mathrm{Pb}$ industrial wastes. Plant Soil 337:299-311

Wierzbicka M, Szarek-Łukaszewska G, Grodzińska K (2004) Highly toxic thallium in plants from the vicinity of Olkusz (Poland). Ecotoxicol Environ Saf 59:84-88

Woch MW, Kapusta P, Stefanowicz AM (2015) Variation in dry grassland communities along a heavy metals gradient. Ecotoxicology. doi 10. 1007/s10646-015-1569-7

Wójcik M, Sugier P, Siebielec G (2014) Metal accumulation strategies in plants spontaneously inhabiting $\mathrm{Zn}-\mathrm{Pb}$ waste deposits. Sci Total Environ 487:313-322

Xiao T, Guha J, Boyle D, Liu CQ, Chen J (2004) Environmental concerns related to high thallium levels in soils and thallium uptake by plants in southwest Guizhou, China. Sci Total Environ 318:223-244

Yoon J, Cao X, Zhou Q, Ma LQ (2006) Accumulation of Pb, Cu, and Zn in native plants growing on a contaminated Florida site. Sci Total Environ 368:456-464 